\title{
Peranan Inokulasi Fungi Mikoriza Arbuskular (FMA) dan Pupuk Fosfat terhadap Produktivitas dan Kandungan Nutrisi Indigofera zollingeriana
}

\author{
Innoculation Role of Micoriza arbuscular Fungi (FMA) and Phosphate Fertilizer on \\ Production and Nutrient Qualty of Indigofera zollingeriana
}

\author{
B. Herlina, Sutejo, dan J. Laksono \\ Program Studi Peternakan Universitas Musi Rawas \\ e-mail: bettyherlina1965@gmail.com
}

\begin{abstract}
This study aims to determine how is the role of inoculation of Arbuscular Fungi Mycorrhiza. To increase Indigofera plant production and nutrient content. This research uses Completely Randomized Design of factorial with 2 factors The first factor is the mycorrhizal fungi with the level of administration of M0: Without Mycorrhizal, M1: $5 \mathrm{gr} /$ polybag, M2: $10 \mathrm{gr} /$ polybag. The second factor was phosphate with treatment, F0: No Phosphate Fertilizer, F1: RP fertilizer 270kg / ha F2: SP-36 fertilizer (36\% P2O5) $150 \mathrm{~kg} / \mathrm{ha}$. The results showed that the mycorrhizal fungi and phosphate had no significant effect $(\mathrm{P}>0.05)$ on plant height, stem diameter, leaf numbers, wet weight of trim, dry-weighted berries, crude protein and crude fiber. Tabulated treatment of M2 (10 gr Mikoriza/ polybag) giving the best results on plant height, stem diameter, leaf number, wet weight, dry weight, crude protein and crude fiber. While, for phosphate treatment (F1) fertilizer RP (20\% P2O5) $270 \mathrm{~kg} / \mathrm{ha} / 1.08 \mathrm{gr} /$ polybag gives the best results for observed parameters, plant height, stem diameter, wet weight of trim, dry weight of trim Mycorrhizal. Interaction with phosphate fertilizer had no significant effect on growth and nutrient content of indigofera plant.
\end{abstract}

Key words: Arbuscular Mycorrhiza Fungi, Phosphate Fertilizer, Indigofera

\begin{abstract}
ABSTRAK
Penelitian ini bertujuan untuk mengetahui seberapa besar peranan inokulasi Fungi Micoriza arbuskular untuk meningkatkan produksi tanaman Indigofera dan kandungan nutrisi. Penelitian ini menggunakan metode Eksperimen dengan Rancangan Acak Lengkap pola faktorial dengan 2 faktor. Faktor pertaman adalah fungi mikoriza dengan level pemberian M0 : Tanpa Mikoriza, M1 : 5 gr / polybag, M2 : 10 gr / polybag. Faktor kedua fosfat dengan perlakuan, F0 : Tanpa Pupuk fosfat, F1 : Pupuk RP 270kg/ha F2 : Pupuk SP-36 $\left(36 \% \mathrm{P}_{2} \mathrm{O}_{5}\right) 150$ $\mathrm{kg} / \mathrm{ha}$. Hasil penelitian menunjukan bahwa fungi mikoriza dan fosfat berpengaruh tidak nyata $(\mathrm{P}>0,05)$ pada peubah tinggi tanaman, diameter batang, jumlah daun, berat basah berangkasan, berat kering berangkasan, protein kasar dan serat kasar. Secara tabulasi perlakuan mikoriza (M2) 10 gr Mikoriza/ polybag memberikan hasil yang terbaik pada peubah tinggi tanaman, diameter batang, jumlah daun, berat basah berangkasan, berat kering berangkasan, protein kasar dan serat kasar. Untuk perlakuan fosfat (F1) Pupuk RP $\left(20 \% \mathrm{P}_{2} \mathrm{O}_{5}\right) 270 \mathrm{~kg} / \mathrm{ha}$ /1,08 gr/polybag memberikan hasil terbaik untuk parameter pengamatan tinggi tanaman, diameter batang, berat basah berangkasan, berat kering berangkasan. Interaksi mikoriza dengan pupuk fosfat berpengaruh tidak nyata terhadap pertumbuhan dan kandungan nutrisi tanaman indigofera.
\end{abstract}

Kata kunci: Fungi Mikoriza Arbuskular, Pupuk Fosfat, Indigofera,

\section{PENDAHULUAN}

Budidaya ternak ruminansia memiliki peranan yang sangat penting dalam peningkatan protein hewani. Tanaman indigofera merupakan salah satu aternatif tanaman pakan yang memiliki potensi sebagai bahan pakan utama untuk perbaikan gizi pada ternak ruminansia. Indigofera memiliki produksi biomasa yang tinggi bila dibandingkan dengan leguminosa pohon lain pada kondisi 
lingkungan yang sama. Menurut Sirait et al. (2009) bahwa I. zollingeriana dapat berproduksi secara optimum pada umur delapan bulan dengan rata-rataproduksi biomasa segar per pohon mencapai 2,6 $\mathrm{kg} /$ panen, rasio produksi daun per pohon $967,75 \mathrm{~g} /$ panen $(37,29 \%)$ dan produksi batang per pohon 1.627,25 $\mathrm{g} /$ panen $(63,57 \%)$ dengan total produksi segar sekitar 52 ton/ha/tahun.

Mengingat potensi nutrisi dan produksinya yang cukup baik, maka perlu diupayakan budidaya yang efektif yang dapat menghasilkan produksi yang stabil. Untuk mengetahui stabilitas tingkat produktivitas tanaman pakan sangat dipengaruhi oleh ketersediaan nutrisi dalam tanah. Pemupukan merupakan upaya meningkatkan ketersediaan nutrisi yang dapat diserap oleh tanaman baik melalui akar maupun stomata daun. Pemupukan dapat dilakukan dengan memanfaatkan pupuk hayati (biofertilizer) seperti Fungi Micoriza arbuskular. Pemanfaatan Fungi Micoriza arbuskular (FMA) merupakan salah satu alternatif dalam meningkatkan produktivitas hijauan makanan ternak, selain itu penggunaan mikoriza arbuskular dapat mendukung pertanian berkelanjutan karena dapat mengurangi penggunaan pupuk anorganik untuk menghasilkan pakan yang lebih sehat. Kolonisasi sistem fungi mikoriza arbuskular menghasilkan manfaat langsung bagi tanaman inang yaitu meningkatkan serapan hara khususnya fosfat, meningkatkan ketahanan terhadap kekeringan, tahan terhadap serangan patogen akar dan mampu menghasilkan zat pengatur tumbuh misalnya auksin, sitokinin, dan giberelin (Imas et al., 1989)

Fospat di dalam tanaman berperan dalam hampir semua proses reaksi biokimia. Peran fospat yang istimewa adalah pada proses penangkapan energi cahaya matahari dan kemudian mengubahnya menjadi energi biokimia. Fospat merupakan komponen penyusun membran sel tanaman, penyusun enzimenzim, sintesis protein, sintesis karbohidrat, memacu pembentukan bunga dan biji (Wijaya, 2004).

Fospat di dalam tanah dalam bentuk P-organik dan $\mathrm{P}$ anorganik. Mineral fosfor anorganik umumnya dijumpai sebagai aluminium dan besi fosfat pada tanah-tanah asam, sedangkan kalsium fosfat mendominasi tanah basa. Berbagai jenis asam-asam organik yang dihasilkan mikroorganisme untuk melarutkan $\mathrm{Al}, \mathrm{Fe}, \mathrm{Ca}$ dan magnesium fosfat, sehingga menghasilkan pelepasan ortofosfat ke dalam larutan tanah.Kelompok organisme yang penting adalah fungi mikoriza arbuskula (FMA) yang dapat memacu serapan fosfor (Handayanto dan Chairiah, 2011). Menurut Jones (1990) menyatakan bahwa respon tanaman terhadap aplikasi pupuk $\mathrm{P}$ dipengaruhi oleh beberapa faktor antara lain jenis tanaman maupun pupuk $\mathrm{P}$ yang digunakan serta ada tidaknya mikoriza efektif di dalam tanah.

\section{MATERI DAN METODE}

Penelitian ini dilakukan di Desa Q Tamba Asri Kecamatan Tugumulyo Kabupaten Musi Rawas dengan ketinggian tempat $\pm 78 \mathrm{~m}$ dpl. Penelitian mulai dari bulan Agustus sampai dengan Oktober 2016.

Bahan-bahan yang digunakan dalam adalah: Bibit Indigofera, fungi mikoriza, pupuk $\mathrm{KCl}$, polybag ukuran 10 $\mathrm{kg}$, fungisida, pupuk urea, pupuk Fospat kapur pertanian (dolomit). Sedangkan alat- 
alat yang digunakan adalah: parang meteran ember timbangan , cangkul alatulis analisa nutrisi dilakukan di laboratorium peternakan Universitas Jambi. Rancangan Acak Lengkap (RAL) pola faktorial dengan 2 faktor perlakuan dan 3 ulangan. Faktor pertaman adalah pupuk Mikoriza dengan perlakuan: $\mathrm{M} 0=$ Tanpa Mikoriza M1 = 5 gr Mikoriza / polybag M2 = 10 gr Mikoriza/ polybag Faktor kedua fosfat F0 : Tanpa Pupuk. F1 : Pupuk RP ( $\left(20 \% \quad \mathrm{P}_{2} \mathrm{O}_{5}\right) \quad 270 \mathrm{~kg} / \mathrm{ha} / 1,08$ gr/polybag F2 : Pupuk SP-36 ( $\left.36 \% \mathrm{P}_{2} \mathrm{O}_{5}\right)$ $150 \mathrm{~kg} / \mathrm{ha} / 0,6 \mathrm{gr} / \mathrm{polybag}$

\section{HASIL DAN PEMBAHASAN}

Hasil analisis ragam peranan inokulasi mikoriza (M) dan Pupuk fosfat (F) terhadap produktivitas dan kandungan nutrisi Indigofera zolligeriana dapat dilihat pada Tabel. 1 terlihat bahwa inokulasi mikoriza (M) dan Pupuk fosfat (F) dan interaksi pada kedua perlakuan (MF) berpengaruh tidak nyata $(\mathrm{P}>0,05)$ pada peubah tinggi tanaman, diameter batang, jumlah daun, berat basah berangkasan, berat kering berangkasan, protein kasar dan serat kasar.

Tabel 1. Hasil analisis keragaman peubah-peubah yang diamati.

\begin{tabular}{|c|c|c|c|c|c|}
\hline \multirow{2}{*}{ No. } & \multirow{2}{*}{ Peubah } & \multicolumn{3}{|c|}{ Perlakuan } & \multirow{2}{*}{$\mathrm{KK}(\%)$} \\
\hline & & $\mathrm{M}$ & $\mathrm{P}$ & MP & \\
\hline 1. & Tinggi Tanaman $(\mathrm{cm})$ & $0,64^{\text {tn }}$ & $2,87^{\mathrm{tn}}$ & $0,69^{\text {tn }}$ & 20,13 \\
\hline 2. & Diameter Batang (mm) & $2,44^{\text {tn }}$ & $2,66^{\mathrm{tn}}$ & $1,03^{\text {tn }}$ & 25,48 \\
\hline 3. & Jumlah Daun per Tanaman (Helai) & $0,23^{\text {tn }}$ & $2,97^{\mathrm{tn}}$ & $2,07^{\text {tn }}$ & 26,19 \\
\hline 4. & Berat Basah Berangkasan (gram) & $0,03^{\mathrm{tn}}$ & $3,62^{\mathrm{tn}}$ & $0,59^{\operatorname{tn}}$ & 27,65 \\
\hline 5. & Berat Kering Berangkasan(gram) & $0,04^{\mathrm{tn}}$ & $3,41^{\text {tn }}$ & $0,62^{\text {tn }}$ & 27,58 \\
\hline 6. & Protein Kasar (\%) & $0,36^{\mathrm{tn}}$ & $0,26^{\mathrm{tn}}$ & $0,51^{\mathrm{tn}}$ & 7,08 \\
\hline 7. & Serat Kasar $(\%)$ & $0,25^{\mathrm{tn}}$ & $0,48^{\text {tn }}$ & $0,51^{\mathrm{tn}}$ & 11,63 \\
\hline
\end{tabular}

Keterangan: M: Fungi Mikoriza, F: Fosfat, MP : Interaksi $M$ dan F, tn : Berpengaruh tidak nyata, KK : Koofisien Keragaman.

Tabel 2. Pengaruh perlakuan terhadap peubah yang diamati

\begin{tabular}{llllllll}
\hline Perlakuan & $\begin{array}{l}\text { TT } \\
(\mathrm{cm})\end{array}$ & $\begin{array}{l}\text { DB } \\
(\mathrm{cm})\end{array}$ & $\begin{array}{l}\text { JD } \\
(\text { helai })\end{array}$ & $\begin{array}{l}\text { BBB } \\
(\mathrm{gram})\end{array}$ & $\begin{array}{l}\text { BKB } \\
(\mathrm{gram})\end{array}$ & $\begin{array}{l}\text { PK } \\
(\%)\end{array}$ & $\begin{array}{l}\text { SK } \\
(\%)\end{array}$ \\
\hline M0PO & 21,00 & 1,86 & 6,33 & 5,94 & 1,19 & 23.33 & 14,00 \\
M0P1 & 21,67 & 3,20 & 4,67 & 4,91 & 1,01 & 22,63 & 14,40 \\
M0P2 & 18,33 & 2,50 & 4,33 & 4,32 & 0,86 & 24,40 & 13,77 \\
M1P0 & 19,67 & 3,07 & 6,67 & 6,17 & 1,23 & 32,50 & 13,33 \\
M1P1 & 25,33 & 3,20 & 7,33 & 7,40 & 1,48 & 24,00 & 14,10 \\
M1P2 & 25,33 & 2,65 & 5,33 & 7,03 & 1,39 & 23,80 & 13,33 \\
M2P0 & 24,67 & 2,89 & 6,33 & 6,68 & 1,32 & 23,37 & 14,33 \\
M2P1 & 25,67 & 3,57 & 6,00 & 7,05 & 1,39 & 24,70 & 12,67 \\
M2P2 & 26,33 & 3,73 & 8,33 & 7,50 & 1,52 & 24,00 & 13,00 \\
\hline Teterangan : TT: Tinggi tanaman, DB: Diameter Batang, JD : Jumlah Daun BBB : Berat Basah Berangkasan
\end{tabular}




\section{Inokulasi Mikoriza}

Hasil analisis keragaman menunjukan bahwa perlakuan mikoriza (M) berpengaruh tidak nyata $(\mathrm{P}>0,05)$ pada semua peubah yang diamati. Hal ini diduga karena optimalisasi pemberian mikoriza pada samping tanaman pada saat tanam bibit indigofera yang belum efektif, di jelaskan oleh Simarmata et al. (2004). dalam rangka meningkatkan keefektifan penggunaan mikoriza, disarankan penggunaan fungi mikoriza diaplikasikan pada saat tanaman masih di persemaian sehingga pada saat tanaman dipindahkan ke lapangan mikoriza telah menginfeksi akar tanaman. Selain itu unsur $\mathrm{P}$ yang dapat diikat oleh aktivitas mikoriza yang tidak optimal juga sangat rendah. Hasil analisis tanah awal menunjukkan jumlah $\mathrm{P}$ dalam tanah 4,46 ppm, dengan jumlah tersebut unsur $\mathrm{P}$ dalam tanah termasuk sangat rendah. Hardjowigeno (2007) menjelaskan, bahwa apabila kandungan $\mathrm{P}$ dalam tanah < 10 ppm maka kandungan tersebut berada pada jumlah yang sangat rendah

Data tabulasi menunjukkan bahwa M2 lebih dari perlakuan M1 dan M0 pada peubah tinggi tanaman, diameter batang, jumlah daun, berat basah berangkasan, berat kering berangkasan, protein kasar dan serat kasar. Hal ini diduga karena pada perlakuan ini efektifitas mikoriza mampu mengikat $\mathrm{P}$ dari dalam tanah dengan jumlah yang lebih besar dibandingkan perlakuan lain, sehingga jumlah $P$ yang diikat tersebut dapat menambah kebutuhan $P$ yang dibutuhkan tanaman indigofera terutama pada peubah-peubah tersebut.
Niswati (1996) menjelaskan, bahwa pemberian takaran fungi mikoriza 10 g/tanamam dapat meningkatkan pertumbuhan dan produksi tanaman.

\section{Pupuk Fosfat.}

Hasil analisis keragaman menunjukan bahwa perlakuan Fosfat (P) berpengaruh tidak nyata $(\mathrm{P}>0,05)$ pada semua peubah pada peubah tinggi tanaman, diameter batang, jumlah daun, berat basah berangkasan, berat kering berangkasan, protein kasar dan serat kasar

Hal ini diduga kerena pemberian pupuk Fosfat berpengaruh secara tidak langsung terhadap pertumbuhan dan kandungan nutrisi tanaman, selain itu adanya unsur lain yang berpengaruh terhadap pertumbuhan tanaman seperti unsur nitrogen. Dijelaskan oleh Wijaya (2004) menjelaskan bahwa, dalam proses pertumbuhan vegetativ tanaman lebih banyak dipengaruhi oleh ketersediaan unsur $\mathrm{N}$ dalam tanah, ditambahkan juga Novizan, (2002) unsur $\mathrm{N}$ pada tanaman berfungsi membentuk asam amino dan protein yang dimanfaatkan dalam memacu pertumbuhan fase vegetatif.

Secara tabulasi perlakuan P1memberikan hasil terbaik untuk parameter pengamatan tinggi tanaman, diameter batang, berat basah berangkasan, berat kering berangkasan. Hal ini di duga karena unsur $\mathrm{P}$ yang yang berasal dari rock phosphate walaupun sifat dari pupuk rock fosfat yang lambat tersedia bagi tanaman diberikan sudah dapat digunakan untuk memenuhi kebutuhan tanaman indigofera, selain itu juga $\mathrm{P}$ berperan penting dalam 
pertumbuhan dan kandungan protein tanaman. Sebagaimana dijelaskan oleh Sutejo (1987), bahwa P berperan penting dalam pembentukan karbonhidrat dan protein dan unsur $P$

Penambahan mikoriza dan ke dalam tanah belum sempat direspon oleh tanaman, sehingga pertumbuhan tanaman masih relatif seragam. Selain itu dalam pertumbuhan tanaman indigofera pada masa vegetatif tanaman memerlukan unsur $\mathrm{N}$ yang cukup untuk pertumbuhannya, karena kandungan unsur $\mathrm{N}$ rendah maka ketersediaannya bagi tanaman belum mencukupi.

\section{Pengaruh interaksi perlakuan.}

Hasil analisis keragaman menunjukan bahwa interaksi (MP) berpengaruh tidak nyata $(\mathrm{P}>0,05)$ pada semua peubah pada peubah tinggi tanaman, diameter batang, jumlah daun, berat basah berangkasan, berat kering berangkasan, protein kasar dan serat kasar

Hal ini di duga karena masingmasing perlakuan tidak saling memberikan pengaruh yang signifikan secara bersamasama terhadap pertumbuhan dan kandungan nutrisi tanaman. Dimana kurannya optimal mikoriza dalam meinfeksi akar tanama sehingga penyerapan $\mathrm{P}$ yang tersedia maupun yang tidak tersedia oleh tanaman tidak dapat terserap secara maksimal. Sehingga hal tersebut menyebabkan tingkat keseragaman pertumbuhan dan kandungan nutrisi tanaman yang sama.

Namun demikian dilihat dari data tabulasi kombinasi dari kedua perlakuan ini memberikan variasi nilai yang mempunyai sedikit perbedaan terhadap pertumbuhan dan kandungan nutrisi tanaman indigofera. Variasi interaksi yang terbaik pada peubah-peubah tanaman pare ini juga disebabkan karena faktor lain diluar perlakuan yaitu tanah. Tanah yang digunakan pada penelitian ini adalah tanah ultisol bersifat masam dimana setelah dilakukan analisa pH mencapai 4,5. Kondisi tersebut mengakibatkan mikoriza sebagai pengurai hara di dalam tanah, peran menjadi tidak terlihat. Sesuai dengan pendapat Rosmarkam dan Yuwono (2002) bahwa kesuburan tanah sangat penting dalam menunjang pertumbuhan tanaman.

Secara tabulasi perlakuan (M2P2) merupakan kombinasi terbaik pada tinggi tanaman, diameter batang, jumlah daun, berat basah brangkasan, berat kering brangkasan. Di duga karena interaksi pemberian mikoriza dan pupuk $\mathrm{P}$ mampu memacu meningkatkan pertumbuhan dan mampu menyediakan unsur $\mathrm{P}$ bagi tanaman indigofera. Hal ini menunjukkan bahwa interaksi pemberian mikoriza dan pupuk $\mathrm{P}$ masih mampu memberikan hasil yang berbeda terhadap pertumbuhan dan produksi tanaman indigofera, meskipun secara statistik memberikan pengaruh yang tidak nyata. Nuhamara (1994) menjelaskan bahwa, mikoriza mampu meningkatkan pertumbuhan dan zat pengatur tumbuh lainnya seperti auksin. Serta Agustina (2004) menjelaskan bahwa, $P$ juga berperan dalam pertumbuhan tanaman, terutama untuk memperkuat dan mempercepat pertumbuhan tanaman. 


\section{KESIMPULAN}

Perlakuan mikoriza berpengaruh tidak nyata terhadap pertumbuhan tanaman indigofera. Secara tabulasi perlakuan mikoriza (M2) 10 gr Mikoriza/ polybag memeberikan hasil yang terbaik pada peubah pada peubah tinggi tanaman, diameter batang, jumlah daun, berat basah berangkasan, berat kering berangkasan, protein kasar dan serat kasar. Sedangkan untuk perlakuan fosfat (F1) Pupuk RP $\left(\begin{array}{lll}20 \% & \mathrm{P}_{2} \mathrm{O}_{5}\end{array}\right) \quad 270 \mathrm{~kg} / \mathrm{ha} / 1,08 \mathrm{gr} /$ polybag memberikan hasil terbaik untuk parameter pengamatan tinggi tanaman, diameter batang, berat basah berangkasan, berat kering berangkasan. Interaksi mikoriza dengan pupuk fosfat berpengaruh tidak nyata terhadap pertumbuhan dan kandungan nutrisi tanaman indigofera.

\section{DAFTAR PUSTAKA}

Akbarillah, T., D. Kaharuddin dan Kusisiyah. 2002. Kajian tepung daun indigofera sebagai suplemen pakan terhadap produksi dan kualitas telur. Laporan Penelitian. Lembaga Penelitian Universitas Bengkulu, Bengkulu

Hassen, A., N. F. G. Rethman, W. A. Z. Apostolides, and Van Niekerk. 2008. Forage Production and Potential Nutritive Value of 24 Shrubby Indigofera Accessions under Field Conditions in South Africa. Tropical Grasslands. 42:96-103
Agustina Lily, 2004. Dasar Nutrisi Tanaman. Rineka Cipta: Jakarta

Harjowigeno S.2007. Ilmu Tanah. Akademika Pressindo: Jakarta

Handayanto dan Chairiah. 2007. Biologi Tanah. Pustaka Adipura, Malang

Imas, T., R. S. Hadioetomo, A. W. Gunawan, dan Y. Setiadi. 1989. Mikrobiologi Tanah II. Pusat Antar Universitas Bioteknologi. Institut Pertanian Bogor. Bogor.

Jones, RJ. 1990. Phosphorus and beef production in northern Australia. 1. Phosphorus and pasture productivity. Trop. Grassld. 24:131-139

Nuhamara, S.T. 1994. Peranan Mikoriza untuk reklamasi lahan Kritis. Program Pelatihan Biologi dan Bioteknologi Mikoriza

Niswati, A. Nugroho, ,SG Utomo M. dan Suryadi. 1996. Pemamfaatan Mikoriza Vasikular Arbuskular untuk mengatasi Pertumbuhan Jagung Akibat Cekaman Kekeringan. Jurnal Ilmu Tanah Fakultas Pertanian: Universitas Lampung. No 3 Lampung

Novizan. 2002. Petunjuk Pemupukan yang Efektif. Agromedia Pustaka. Jakarta. 
Rosmarkam, A dan N.W. Yuwono. 2002.

Ilmu Kesuburan Tanah.

Kanisius, Yogyakarta.

Simanungkalit, R.D.M. 2002. Cendawan mikoriza arbuskular. http//www. Pupukhayati.go.id. (di akses april 2015)

Sinwin, R.M. 2006. Peranan kascing dan inokulasi mikoriza terhadap serapanhara Tanaman jagung. UNRAM

Simarmata, T. 1994. Teknologi Pupuk Organik. Dalam Akyas, A.M. T. Pudjianto, T. Simarmata, D. Widayat dan C. Tjahyadi (Eds). Penulisan Budidaya Buahbuahan (Mangga). Dirjen Tanaman Pangan, Departemen Pertanian: 143-152

Sirait J, Simanihuruk K, Hutasoit R. 2009. The potency of Indigofera sp. As goat feed: production, nutritive value and palatability. In: Proceeding of
International Seminar on Forage Based Feed Resources. Bandung, 3-7 Agustus 2009. Taipei (Taiwan): Food and Fertilizer Technology Centre (FFTC) ASPAC, Livestock Research Centre-COA, ROC and IRIAP. P. 4-7.

Schrire, B. D. 2005. Tribe Indigofereae. In : Marquiafa`vela, FS, Ferreirab MDS, Teixeiraa SP. Novel reports of glands in neotropical species of Indigofera L. (Leguminosae, Papilionoideae). J. Flora. 204:189-197.

Tarigan, A., L. Abdullah, S. P. Ginting dan I G. Permana. 2010. Produksi dan komposisi serta nutrisi In vitro Indigofera sp. Pada interval dan tinggi pemotongan berbeda. Jurnal Ilmu Ternak dan Veteriner, 15(3): 188-195.

Wijaya, K.A. 2004. Nutrisi tanaman. Penebar Swadaya: Jakarta. 